\title{
The effect of high energy milling and high thermal treatment on the structure and thermal decomposition of minerals from natural $\mathrm{CaO}-\mathrm{SiO}_{2}-\mathrm{P}_{2} \mathrm{O}_{5}$ ceramic system
}

\author{
Bilyana Kostova $^{a}$, Vilma Petkova ${ }^{\mathrm{b}, *}$, Ventseslav Stoyanov ${ }^{\mathrm{c}}$, Zh. Uzunov $^{\mathrm{d}}$

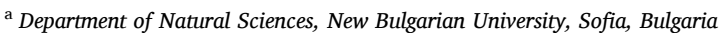 \\ b Institute of Mineralogy and Crystallography "Acad. Iv. Kostov", Bulgarian Academy of Sciences, Bulgaria \\ c University of Structural Engineering and Architecture (VSU) „Lyuben Karavelov“, Bulgaria \\ ${ }^{\mathrm{d}}$ Department of Archeology, New Bulgarian University, Sofia, Bulgaria
}

\section{A R T I C L E I N F O}

\section{Keywords:}

$\mathrm{CaO}-\mathrm{SiO}_{2}-\mathrm{P}_{2} \mathrm{O}_{5}$ system

High energy milling

Thermal activation

Thermal analysis

Reaction mechanisms

\begin{abstract}
A B S T R A C T
The major issue studied in this paper is a natural mineral aggregate of quartz, calcite, and fluorapatite (the raw material originated from Bulgaria) before and after high energy milling and thermal treatment, in the order to investigate the properties of natural $\mathrm{CaO}-\mathrm{SiO}_{2}-\mathrm{P}_{2} \mathrm{O}_{5}$ ceramic system. The activation effects are monitored by chemical analysis, X-ray powder diffraction, Fourier transformed infrared spectroscopy, and Thermal analysis (TG/DTG).

The activation effect study shows: (i) change of chemical bond strength; (ii) deformation of structural polyhedrons with the formation of new isomorphic phases; (iii) the prolonged time of HEM activation leads to lower raw mineral stability and to the formation of new phases; iv) increased $\mathrm{SiO}_{2}$ reactivity resulting in solid-phase crystallization.

The obtained results can be used in the study of ceramic and cement materials (ancient and modern), soil conditioners, etc.
\end{abstract}

\section{Introduction}

The natural mixture of apatite, quartz, and calcite is a well-known system $\left(\mathrm{CaO}-\mathrm{SiO}_{2}-\mathrm{P}_{2} \mathrm{O}_{5}\right)$ investigated by many authors as a source of bone bioactive ceramic [1,2], ancient and modern cement [3-7], ceramic composites [8-12], phosphorus fertilizers, and soil improvers, [13-16].

Apatite is the name of a mineral group consisting of several isomorphic minerals with end members hydroxyl-apatite (HAp), fluorapatite (FAp), and chlorite-apatite [17]. The object of interest is intermediate members of this series, characterized by the partially isomorphic substitution of $\mathrm{PO}_{4}, \mathrm{OH}$ and $\mathrm{F}$, forming hydroxyl-flour-apatite (HFAp), carbonate-hydroxyl-flour-apatite (CHFAp), etc., after high energy milling (HEM) treatment [18]. HEM treatment of solids causes the appearance of strain field, i. e. the solids accumulated energy in strain field. The accumulated energy relaxed into heat. The other way to energy relaxation is solid plastic deformation, which can lead to the destruction of the crystal (crushing). During high-energy milling, the size of crystals decreases to some critical values. Further energy supply to these crystals of limiting size causes further deformation of crystals, energy accumulation in the volume or at the surface of crystals, and subsequently amorphization/or transition into a metastable polymorphous state/or rupture of chemical bonds [19-21]. Suitable methods for studying such a system are powder diffraction X-Ray analysis, FTIR spectroscopy and thermal analysis [22-30].

The studied raw material (natural $\mathrm{CaO}-\mathrm{SiO}_{2}-\mathrm{P}_{2} \mathrm{O}_{5}$ system) is from

\footnotetext{
Abbreviations: A-type isomorphism, the isomorphic substitution of $\mathrm{OH}^{-}$by $\mathrm{CO}_{3}$ in the apatite structure; A-B-type isomorphism, the isomorphic substitution of $\mathrm{PO}_{4}$

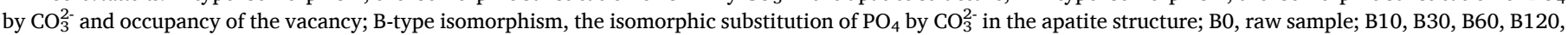

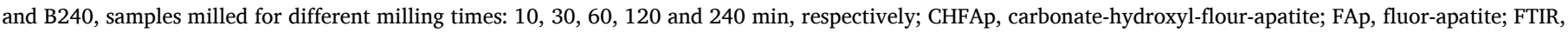

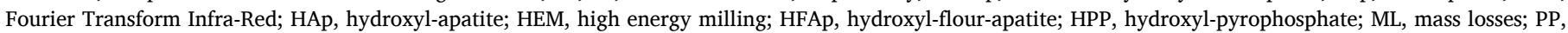
pyrophosphate; PXRD, powder X-ray diffraction; RT, room temperature; SSA, specific surface area; TCP, tricalcium phosphate; TG-DTG, Thermal analyses.

* Corresponding author at: Institute of Mineralogy and Crystallography, Bulgarian Academy of Sciences, Acad. G. Bonchev Str., build.107, 1113 Sofia, Bulgaria.

E-mail addresses: bkostova@nbu.bg (B. Kostova), vilmapetkova@gmail.com, vpetkova@clmc.bas.bg (V. Petkova), vensy.stoyanov@gmail.com, vensy.stoyanov@ vsu.bg (V. Stoyanov), zhuzunov@nbu.bg (Zh. Uzunov).
} 
Sanadinovo, Bulgaria, where the quartz is in higher quantity, followed by calcite and apatite. It was studied in the past and defined as lowphosphate and unpromising ore for agriculture because of the high quantity of $\mathrm{SiO}_{2}$ and $\mathrm{CaCO}_{3}$, as well as the low quantity of $\mathrm{P}_{2} \mathrm{O}_{5}[15,31]$. This mixture was not studied for the properties of the system after HEM and thermal treatment of milled samples. The $\mathrm{CaO}-\mathrm{SiO}_{2}-\mathrm{P}_{2} \mathrm{O}_{5}$ is part of ancient and modern cement and ceramic composites whose behavior at milling, rising temperature and atmospheric conditions $\left(\mathrm{CO}_{2}\right.$ and $\left.\mathrm{H}_{2} \mathrm{O}\right)$ is of practical importance for the clinker and ceramic minerals obtained as a result. The study of ancient building composite manufacturing technologies, as well as, used local raw materials for their production with practical application in archaeomineralogy and archaeological chemistry which contributes to knowledge of ancient environment. In the future, the low-phosphate ores could become an essential resource for agriculture due to the depletion of rich phosphor ores. The mentioned above the features of the $\mathrm{CaO}-\mathrm{SiO}_{2}-\mathrm{P}_{2} \mathrm{O}_{5}$ system justified studying its properties after HEM and thermal treatment.

\section{Experimental}

Natural sedimentary mineral aggregate from Bulgaria has been investigated (sample B0) with chemical composition (mass $\%$ ): $38.97 \%$ $\mathrm{SiO}_{2}, 26.34 \% \mathrm{CaO}, 14.61 \% \mathrm{P}_{2} \mathrm{O}_{5}^{\text {tot }}, 7.91 \% \mathrm{R}_{2} \mathrm{O}_{3}\left(\mathrm{R}_{2} \mathrm{O}_{3}=\mathrm{Fe}_{2} \mathrm{O}_{3}+\mathrm{Al}_{2} \mathrm{O}_{3}\right)$ $2.63 \% \mathrm{~F}_{2}, 2.10 \% \mathrm{~K}_{2} \mathrm{O}, 1.13 \% \mathrm{Na}_{2} \mathrm{O}, 0.95 \% \mathrm{SO}_{\mathrm{x}}, 0.84 \% \mathrm{MgO}$.

The B0 sample was activated via high energy milling (HEM) for different milling times: $10,30,60,120$, and $240 \mathrm{~min}$, where the milled samples were named B10, B30, B60, B120, and B240 respectively. The HEM activation was carried out in a planetary mill Pulverisette-5, Fritsch Co (Germany), using both Cr-Ni plain steel for the milling container of $250 \mathrm{~mL}$ volume and for the milling balls with a diameter of $20 \mathrm{~mm}$ and mass of $510 \mathrm{~g}$. The treatment was implemented at a milling velocity of $320 \mathrm{rpm}$ and the balls-to-powder mass ratio was 25.5:1 and sample mass of $20 \mathrm{~g}$.

All samples (B0, B10, B30, B60, B120, and B240) were thermally activated at a temperature of $1050^{\circ} \mathrm{C}$.

The specific surface area (SSA) measurements were performed by the BET-method (adsorptive gas $\mathrm{N}_{2}$, carrier gas $\mathrm{He}$, heating temperature $150^{\circ} \mathrm{C}$ ) using an EMS-53 sorptometer and KELVIN 1040/1042 software (Costech International).

The powder X-ray diffraction (PXRD) measurements were made by D2 Phaser BrukerAXS, $C u K_{\alpha}$ radiation $(\lambda=0.15418 \mathrm{~nm})$ (operating at $30 \mathrm{kV}, 10 \mathrm{~mA}$ ) from 5 to $80^{\circ} 2 \theta$ with a step of $0.05^{\circ}$ (ground sample weight $-1.0 \pm 0.1 \mathrm{mg}$ and particle size below $0.075 \mathrm{~mm}$. The PDF (Powder Diffraction File, ICDD, 2001) database was used for determining the phases and minerals in the samples [32].

The Fourier Transform Infra Red (FTIR) spectra were registered on Bruker Tensor 37 spectrometer in the range $400-4000 \mathrm{~cm}^{-1}$, using $\mathrm{KBr}$ pellet technique. A resolution of $2 \mathrm{~cm}^{-1}$ was used collecting 60 scans for each sample.

Thermal analyses (TG-DTG) were performed on a LABSYS evo thermal analyzer (SETARAM, France) in the temperature range: room temperature (RT) $-1050{ }^{\circ} \mathrm{C}$ in air medium, with heating rate of $10^{\circ} \mathrm{C} \cdot \mathrm{min}^{-1}$.

\section{Results}

\subsection{SSA measurements}

Fig. 1 shows the results from the SSA measurements proving the dependence on SSA changes of HEM activation time. The HEM activated sample at 10 min displays the intensive increase of the SSA. After $10 \mathrm{~min}$ of HEM activation, the SSA decreases exponentially, while the solid line is the best fit: $y=9.56 \exp (-x / 90.92)+2.82\left(\mathrm{R}^{2}=0.99\right)$.

\subsection{PXRD analysis}

Table 1 and Fig. 2 present the results from PXRD analysis. Sample B0

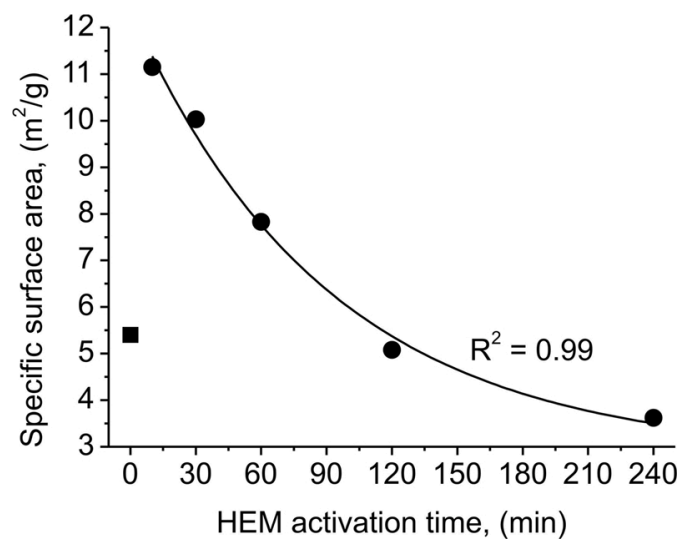

Fig. 1. SSA as a function of HEM activation time: (-) samples with exponential decay dependence of the SSA and the best fit to these data (solid line) (B10, B30, B60, B120, and B240); ( $\mathbf{\square}$ ) sample outside exponential dependence (B0).

shows the quartz $-\mathrm{SiO}_{2}$, calcite $-\mathrm{CaCO}_{3}$, and $\mathrm{FAp}-\mathrm{Ca}_{5} \mathrm{~F}\left(\mathrm{PO}_{4}\right)_{3}$ raw minerals, identified in all HEM-activated samples, as well. Three newlyformed phases were also found in the HEM activated samples: hydroxylpyrophosphate (HPP) - $\mathrm{CaH}_{2} \mathrm{P}_{2} \mathrm{O}_{7}$ (B30, B60, B120 and B240), HFAp $\mathrm{Ca}_{10}\left(\mathrm{PO}_{4}\right)_{6}(\mathrm{OH}, \mathrm{F})_{2} \quad(\mathrm{~B} 60, \quad \mathrm{~B} 120$ and $\mathrm{B} 240)$ and CHFAp $\mathrm{Ca}_{10}\left(\mathrm{PO}_{4}\right)_{5}\left(\mathrm{CO}_{3}\right)(\mathrm{OH}, \mathrm{F})_{3}(\mathrm{~B} 60, \mathrm{~B} 120$ and $\mathrm{B} 240)$. The mineral phases for thermally activated samples are different. The raw calcite is missing, while the raw quartz and FAp have been established for all samples. The HFAp formed during HEM activation has been preserved in B10 and B240. The identified new phases are: spurrite $\left(\mathrm{Ca}_{5}\left(\mathrm{SiO}_{4}\right)_{2}\left(\mathrm{CO}_{3}\right)\right)$, silicocarnotite $\left(\mathrm{Ca}_{5}\left(\mathrm{PO}_{4}\right)_{2} \mathrm{SiO}_{4}\right)$ and tilleyite $\left(\mathrm{Ca}_{5} \mathrm{Si}_{2} \mathrm{O}_{7}\left(\mathrm{CO}_{3}\right)_{2}\right)$ presented in $\mathrm{B} 10, \mathrm{~B} 30, \mathrm{~B} 60, \mathrm{~B} 12$ and $\mathrm{B} 240$; calcium pyrophosphate (PP) $\mathrm{Ca}_{2} \mathrm{P}_{2} \mathrm{O}_{7}$ (B30, B60, B12 and B240) and tricalcium phosphate (TCP) $\alpha, \beta-\mathrm{Ca}_{3}\left(\mathrm{PO}_{4}\right)_{2}$ (B0, B120, B240). The peaks of spurrite are of low intensity because of lower crystal size or of small quantity, close to limits of detection of PXRD.

\subsection{FTIR measurements}

The FTIR measurements show the vibration modes of the $\mathrm{SiO}_{2}, \mathrm{SiO}_{4}$, $\mathrm{Si}_{2} \mathrm{O}_{7}, \mathrm{PO}_{4}, \mathrm{P}_{2} \mathrm{O}_{7}, \mathrm{CO}_{3}$, and $\mathrm{OH}$ groups. The obtained FTIR spectra of $\mathrm{B} 0$ and samples after HEM and thermal activation are shown in Fig. 3.

The $\mathrm{SiO}_{2}$ group shows the absorption bands for all investigated samples at $\sim 514, \sim 687, \sim 775, \sim 795, \sim 1092 \mathrm{~cm}^{-1}$, and $\sim 1872 \mathrm{~cm}^{-1}$, assigned as Si-O in quartz [33-36]. The $\mathrm{Si}-\mathrm{O}$ symmetric $\left(\nu_{1}\right)$ and asymmetric $\left(\nu_{3}\right)$ stretching vibrations are presented at $798-800 \mathrm{~cm}^{-1}$ and $1085-1092 \mathrm{~cm}^{-1}$. The asymmetric $\left(\nu_{3}\right)$ stretching vibrations at $1085-1092 \mathrm{~cm}^{-1}$ can be assigned both to $\mathrm{Si}-\mathrm{O}-\mathrm{Si}$, and $\mathrm{P}-\mathrm{O}-\mathrm{P}$ in $\mathrm{SiO}_{2}$ and $\mathrm{PO}_{4}$, respectively. The absorption bands at $463-468 \mathrm{~cm}^{-1}\left(\nu_{2}\right)$ and $512-514 \mathrm{~cm}^{-1}\left(\nu_{4}\right)$ are attributed to the typical bending vibrations of $\mathrm{Si}-\mathrm{O}-\mathrm{Si}[2]$.

The $\mathrm{SiO}_{4}$ group is presented with peaks at $\sim 902$ and $\sim 938 \mathrm{~cm}^{-1}$, assigned as $\left(\nu_{4}\right)$ bending vibration mode of $\mathrm{Si}-\mathrm{O}$ in $\mathrm{SiO}_{4}$ in spurrite [33]. The $\mathrm{Si}_{2} \mathrm{O}_{7}$ group shows a peak at $\sim 646\left(\nu_{4}\right)$ bending vibration mode, assigned as $\mathrm{Si}-\mathrm{O}$ in tilleyite [33]. Both $\mathrm{SiO}_{4}$ and $\mathrm{Si}_{2} \mathrm{O}_{7}$ have been identified in thermally treated samples only.

The $\mathrm{PO}_{4}$ group of FAp shows absorption bands at $\sim 463, \sim 572$, $\sim 599, \sim 1046$ and $\sim 1096 \mathrm{~cm}^{-1}$ for all HEM activated samples [37]. All bands with a shift of several $\mathrm{cm}^{-1}$ have been presented in all thermally treated samples [33,38]. At thermally treated samples, the band of around $420 \mathrm{~cm}^{-1}$ appears, assigned as symmetric $\mathrm{O}-\mathrm{P}-\mathrm{O}\left(\nu_{2}\right)$ bending mode in $\beta-\mathrm{TCP}$.

The $\mathrm{P}_{2} \mathrm{O}_{7}$ group has been established at $\sim 963 \mathrm{~cm}^{-1}$ for all thermally treated samples, assigned as double degenerated symmetric $\mathrm{P}-\mathrm{O}-\mathrm{P}$ $\left(\nu_{1}\right)$ stretching mode in PP $[23,39,40]$. The $\mathrm{P}_{2} \mathrm{O}_{7} / \mathrm{H}_{2} \mathrm{P}_{2} \mathrm{O}_{7}$ group in HPP is difficult to identify in the spectra of HEM activated samples due to low 
Table 1

Results from the PXRD phase analyses.

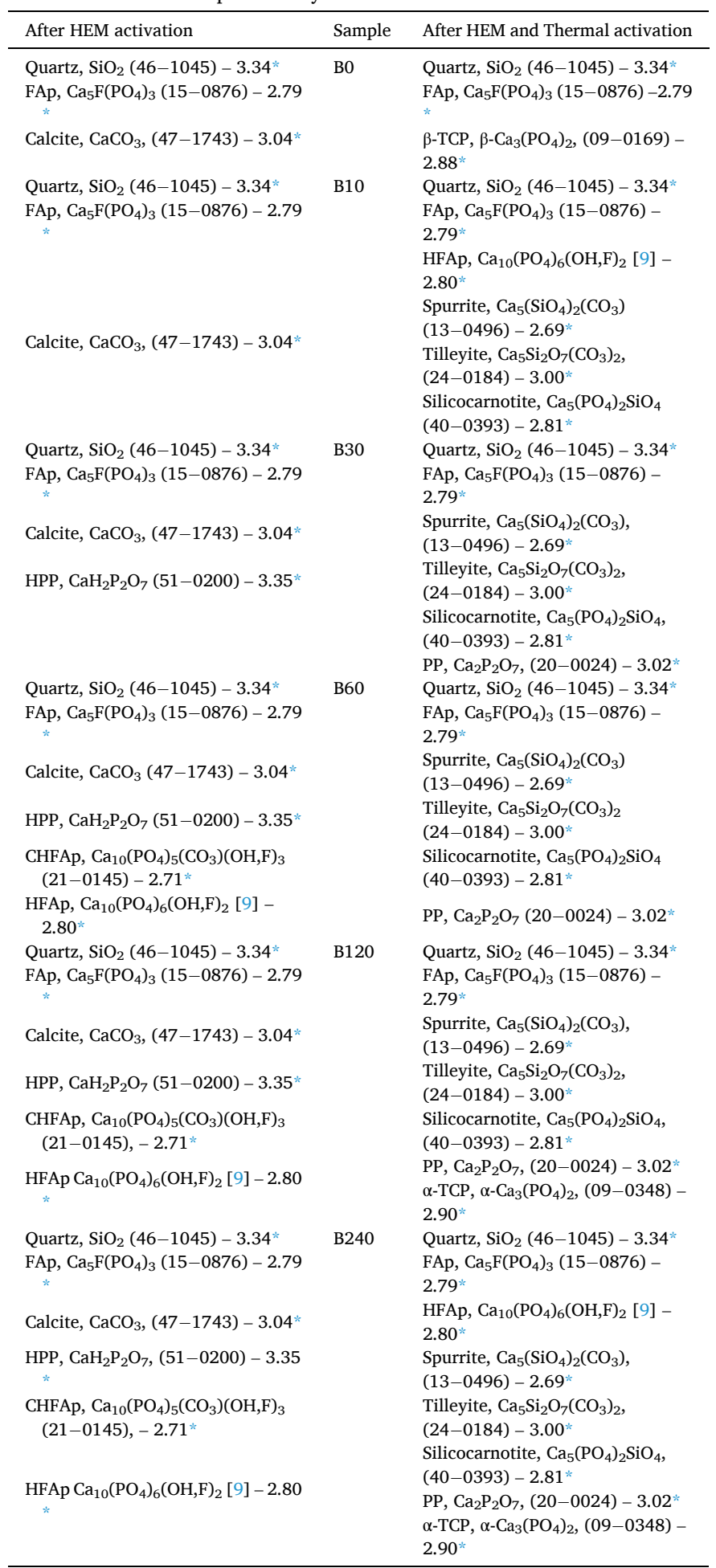

* strongest line.

peak intensities and their overlapping with other peaks. The peaks at $\sim 414 \mathrm{~cm}^{-1}\left(\nu_{2}\right)$ (inserted in peak at $\left.\sim 463 \mathrm{~cm}^{-1}\right) ; \sim 568 \mathrm{~cm}^{-1}\left(\nu_{4}\right)$ (inserted in peak at $\left.\sim 572 \mathrm{~cm}^{-1}\right) ; \sim 732 \mathrm{~cm}^{-1}\left(\nu_{1}\right)$ and $\sim 915 \mathrm{~cm}^{-1}\left(\nu_{1}\right)$ (inserted in peak at $\sim 1048 \mathrm{~cm}^{-1}$ ); and $\sim 1114 \mathrm{~cm}^{-1}\left(\nu_{3}\right)$ ) have been taken with a high probability of HPP crystallization in these samples [41].

In all studied samples peaks appear at 2360 and $2344 \mathrm{~cm}^{-1}$ due to $\mathrm{CO}_{2}$ absorption from the air [38]. The doublet stayed unchanged after
HEM- and thermal treatment of the samples.

Absorption bands at $\sim 875 \mathrm{~cm}^{-1}$ and in the range of $1400-1600 \mathrm{~cm}^{-1}$ are attributed to $\left(\nu_{3}\right) \mathrm{CO}_{3}$ symmetric and asymmetric stretching modes and as $\left(\nu_{2}\right) \mathrm{CO}_{3}$ stretching modes in apatite structure $[33,38]$. They are typical of all HEM-activated samples. The band at the $1400-1600 \mathrm{~cm}^{-1}$ range dramatically decreases in intensity, while the peak at $\sim 875 \mathrm{~cm}^{-1}$ is absent for all thermally treated samples. The peak positions of HEM activated samples are obtained by multiple peak deconvolution applying Gauss function (Table 2).

Absorption bands at $\sim 2500$ and $\sim 2874$ are assigned to $\mathrm{CO}_{3}$ in calcite [33]. They are typical of B0 and all HEM activated samples and stay in practically unchanged positions, and are missing in the thermally activated samples.

Absorption bands at $3200-3800 \mathrm{~cm}^{-1}$ and $\sim 1797 \mathrm{~cm}^{-1}$ are assigned to structural OH-groups in apatite structure (stretching modes) [33]. The broad band at $3200-3800 \mathrm{~cm}^{-1}$ is composed of three peaks and their position is obtained by peak deconvolution by Gauss function of experimental FTIR measurements (Table 2). The $\mathrm{OH}$-bands are presented in all HEM activated samples and the B0 sample. The exact peak positions of all samples are shown in Table 2. The thermally activated samples show a significant intensity decrease of the band at 3500 $3800 \mathrm{~cm}^{-1}$ and no peak at $\sim 1790 \mathrm{~cm}^{-1}$.

The peak at $\sim 1630 \mathrm{~cm}^{-1}$, found in HEM activated samples, is assigned as crystal bonded $\left(\nu_{2}\right)$ OH-group in HPP [40,41]. For thermally activated samples this peak vanishes.

\subsection{Thermal analysis}

Table 3 and Fig. 4 show the results from the thermal analysis of B0 and HEM activated samples. The results prove thermal decomposition of carbonate phases and new solid-phase formation after HEM activation. The thermal reactions complete with a total of $11-12 \%$ mass losses (ML). For sample B0, the temperature stages are: RT-200 ${ }^{\circ} \mathrm{C}(0.40 \%$ $\mathrm{ML}), \quad 200-510^{\circ} \mathrm{C}(2.34 \% \mathrm{ML}), 590-750{ }^{\circ} \mathrm{C}(5.74 \% \mathrm{ML})$ and $800-910^{\circ} \mathrm{C}(1.44 \% \mathrm{ML})$.

The decomposition of HEM activated samples is characterized by parallel thermal reactions in which low values of ML are measured. The ML of HEM activated samples are distributed in the following three temperature intervals: $50-370^{\circ} \mathrm{C}(0.53-2.70 \% \mathrm{ML}) ; 430-530{ }^{\circ} \mathrm{C}$ $\left(0.72-1.67 \% \mathrm{ML}\right.$ ) and $530-920^{\circ} \mathrm{C}$ (decrease from $6.40 \%$ to $4.56 \%$ $\mathrm{ML}$ ). ML decreases in the third temperature range, while an increase is measured in the first two. The four stages of decomposition have been distinguished in the third temperature range marked in Table 3 with No $3,4,5$, and 6 , respectively.

\section{Discussion}

The obtained experimental results of BET method, PXRD analysis, FTIR spectroscopy, and Thermal analysis for all studied samples agree.

\subsection{The BO raw sample}

The PXRD measurement shows the following mineral composition: quartz, calcite, and FAp. The FTIR spectroscopy confirms the presence of quartz and calcite and gives new data on the chemical composition of FAp. The peaks position of $\left(\nu_{3}\right) \mathrm{CO}_{3}^{2-}$ (Table 2) evidence the isomorphic substitution of $\mathrm{PO}_{4}$ by $\mathrm{CO}_{3}^{2-}$, while the $\mathrm{OH}$ - band at $\sim 3550 \mathrm{~cm}^{-1}$ shows the isomorphic substitution of F- by OH- in FAp. The defect substitution of $\mathrm{PO}_{4}$ by $\mathrm{CO}_{3}^{2-}$ is quite known both in literature [17,18,25,28-30,43] and our previous investigations [24,27], known as B-type substitution. The $200-500{ }^{\circ} \mathrm{C}$ temperature interval shows a weak step in the TG curve (Fig. 4a, Table 3) with $1.23 \%$ ML caused by burning a small amount of organic matter. The presence of organic matter is related to the sedimentary origin of B0. After HEM activation, this effect overlaps with the dehydroxylation process without a significant influence on the reaction mechanism of thermal decomposition of HEM activated samples. 

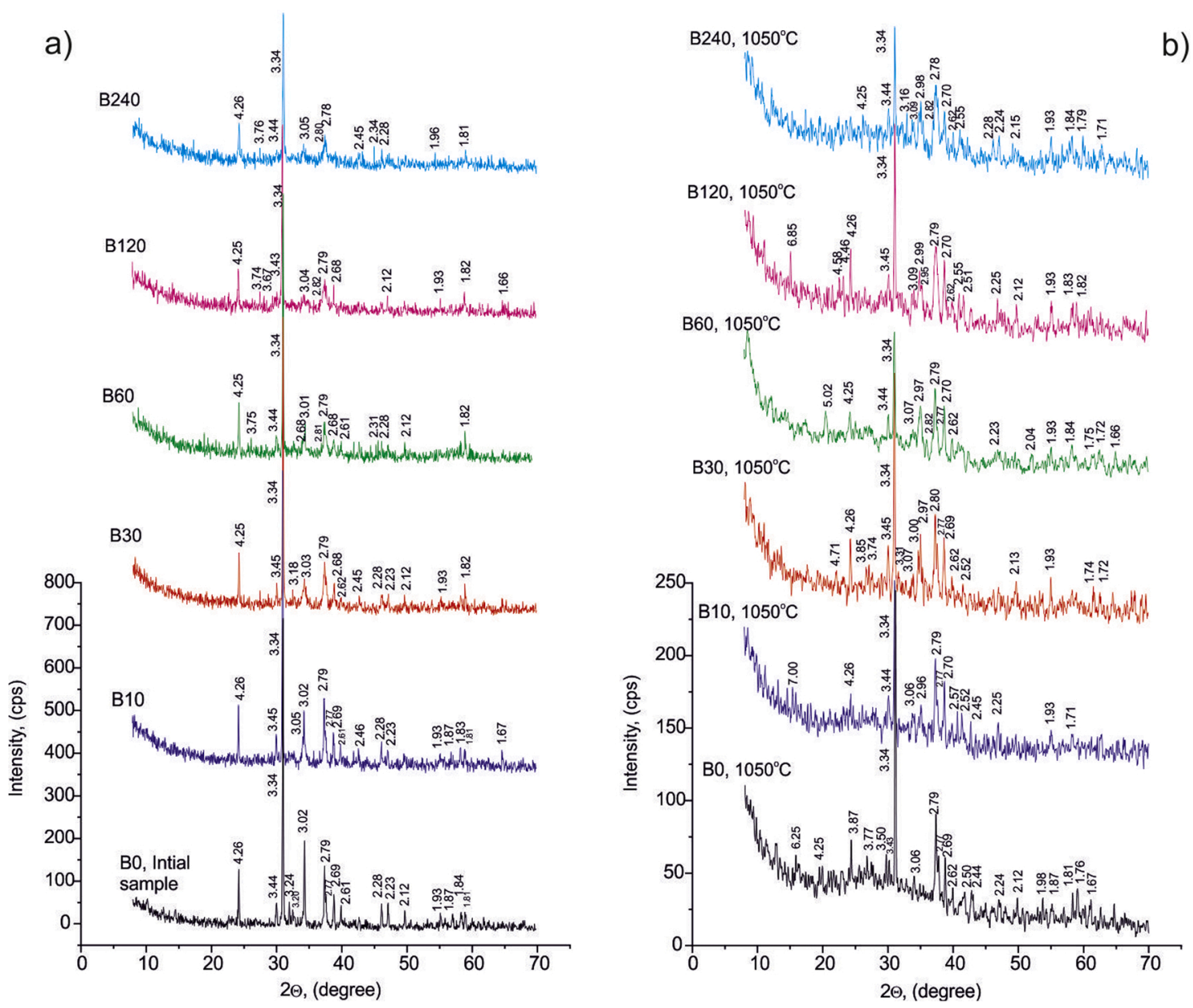

Fig. 2. PXRD patterns of $B 0$ and HEM activated samples: (a) measurements at RT; (b) measurements after thermal activation at $1050{ }^{\circ} \mathrm{C}$.

The general formula of such apatite is $\mathrm{Ca}_{(10-x+u)}\left(\mathrm{PO}_{4}\right)_{6-x}\left(\mathrm{CO}_{3}\right)_{x} \mathrm{~F}_{(2-x+2 u)}$, where $0 \leq x<2$ and $0 \leq u<1[17,18,22]$. According to our results, the chemical formula of $\mathrm{B} 0$ is $\mathrm{Ca}_{10}\left(\mathrm{PO}_{4}\right)_{5}\left(\mathrm{CO}_{3}\right)$ $(\mathrm{OH}) \mathrm{F}_{2}$, where $x=1$ and $u=1$. The low degree of isomorphic substitutions is probably a reason for PXRD identification of raw material as FAp.

\subsection{HEM activated samples}

The raw minerals: quartz, FAp, and calcite have been identified in all samples by PXRD and FTIR. For B10 sample they remain the only mineral phases. This has been confirmed by BET analysis results (Fig. 1) - the maximum of SSA is measured for B10 because of mechanical fragmentation of the sample, without the formation of new mineral phases because of quartz and FAp low chemical activity [17,18]. The prolonged time of HEM activation leads to exponential decrease of SSA due to crystal aggregates formation $[19,21]$. For the B30 - B240, the new mineral (HPP) and new isomorphic members of the apatite group (HFAp and CHFAp) arise, proven by PXRD and FTIR.

The quartz, having strong covalent bonds, high hardness ( 7 by Mohs), and high melting point, remains chemically inactive during HEM activation: (i) PRXD patterns show decreasing peaks intensity without any broadening for B10 - B240 (Fig. 2), in accordance with decreasing SSA after HEM activation (Fig. 1) and (ii) FTIR measurements show practically unchanged Si-O vibration modes of quartz (Fig. 3).

FAp and calcite are with lower hardness - 5 and 3 by Mohs, respectively, and with lower melting points. Therefore, the effect of HEM activation is greater - the intensity decrease of PXRD is obvious, as well as the formation of new minerals (Figs. 2, 3 and Table 1).
The crystallization of HPP is a result of P-ions direct pairing (catenation) with pyrophosphates $\left[\mathrm{H}_{2} \mathrm{P}_{2} \mathrm{O}_{7}\right]^{2-}$ formation (Table 2), skipping ortophosphates - $\left[\mathrm{H}_{2} \mathrm{PO}_{4}\right]$ - and/or $\left[\mathrm{HPO}_{4}\right]^{2-}[47-49]$.

The formation of HFAp and CHFAp is proven by both PXRD and FTIR. The presence of peaks close to 1418, 1458, and $875 \mathrm{~cm}^{-1}$ evidence the B-type isomorphic substitution structure $[17,18]$. The $\sim 1515 \mathrm{~cm}^{-1}$ peak shows the isomorphic substitution of $\mathrm{OH}-$ by $\mathrm{CO}_{3}$ in the apatite structure, known as A-type substitution [46]. Theoretically, the charge compensation at heterovalent substitution is most frequently realized by the occurrence of cationic vacancy $[18,50]$. The $\sim 875 \mathrm{~cm}^{-1}$ peak presents the A-type substitution in all samples, while due to B-type substitution, the band splitting for B120 and B240 and the presence of two additional peaks at 862 and $868 \mathrm{~cm}^{-1}$ have been observed $[18,51]$. The cationic vacancy at the Ca positions, formed during the HEM activation, is very likely to be occupied by $\mathrm{CO}_{2}$ adopted from the air or by migrating $\mathrm{CO}_{3}$-ions which leads to the third type of isomorphic substitution, namely A-B-type. The appearance of A-B-type isomorphism is proved by shifting of the peak close to $\sim 1515 \mathrm{~cm}^{-1}$ to a higher wavenumber (Table 2) [18]. Additional evidence for isomorphism in the $\mathrm{CaO}-\mathrm{P}_{2} \mathrm{O}_{5}$ system has been obtained from the thermal analysis.

The maximum at $\sim 3570 \mathrm{~cm}^{-1}$ shows substitution of $\mathrm{OH}-$ by $\mathrm{CO}_{3}[18$, 38]. As a result, the isomorphic transformation from raw FAp to HCFAp occurs. The probable mechanism of such type of substitution is determined by: (i) adsorption of $\mathrm{CO}_{2}$ from the air [52] and (ii) partial decomposition of calcite and relocation and migration of $\mathrm{CO}_{3}$ in the tetragonal positions of the phosphate ions in the course of HEM-activation. It is known that peak intensity close to $3550 \mathrm{~cm}^{-1}$ decreases with the increase of $\mathrm{CO}_{3}$ content in the apatite structure and the area of $\nu_{1}, \nu_{2}$, and $\nu_{3} \mathrm{CO}_{3}$ peaks increases with the rise of $\mathrm{CO}_{3}$ [46]. On 

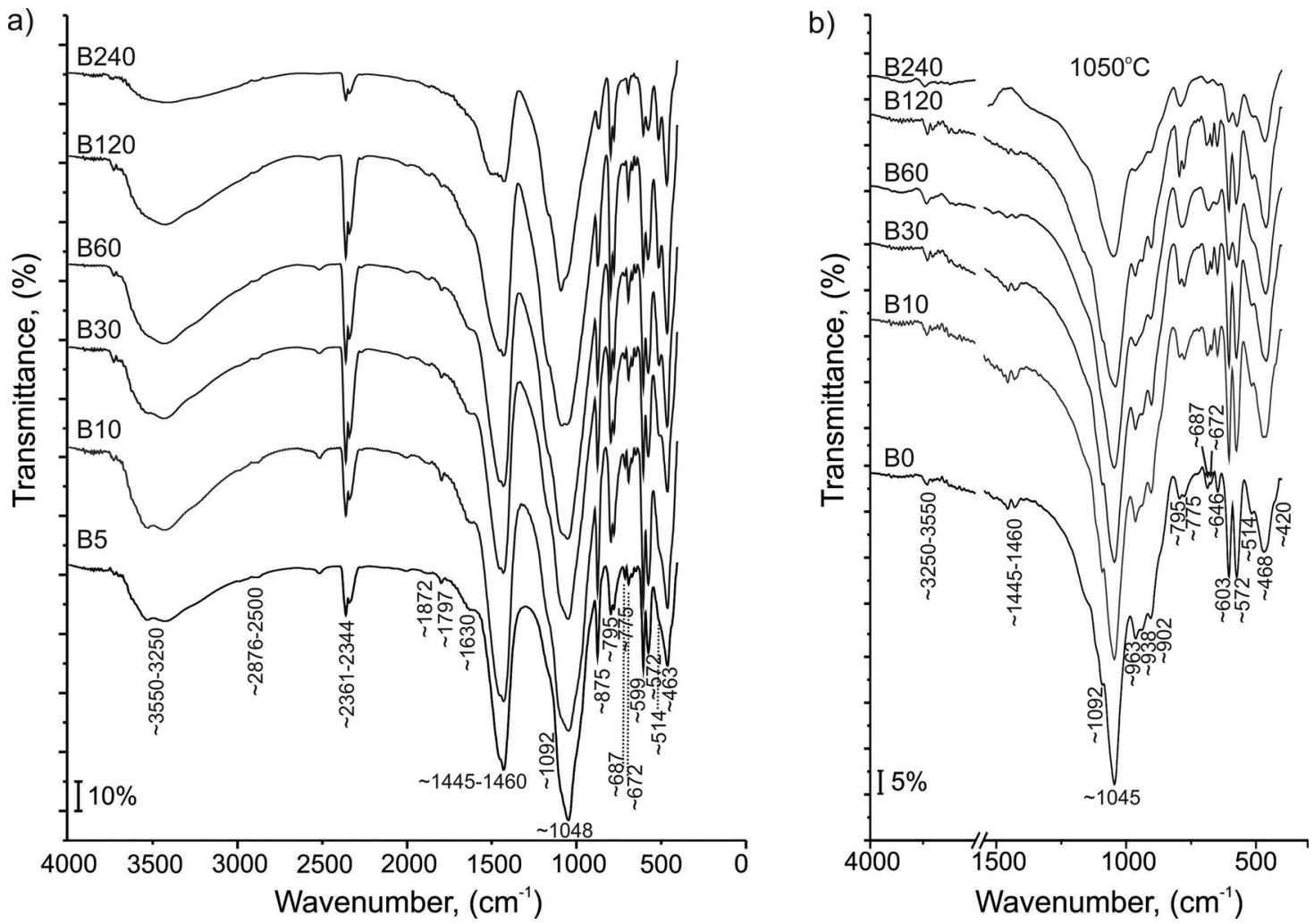

Fig. 3. FTIR spectra of: (a) B0 and HEM-activated samples; (b) B0 and thermally activated samples.

Table 2

Peak positions of $\mathrm{CO}_{3}$ and $\mathrm{OH}$ vibration modes in apatite.

\begin{tabular}{|c|c|c|c|c|c|c|c|c|c|c|c|}
\hline \multirow{3}{*}{$\begin{array}{l}\text { sample } \\
\text { в0 }\end{array}$} & \multicolumn{7}{|l|}{$\mathrm{CO}_{3}$} & \multicolumn{4}{|l|}{$\mathrm{OH}$} \\
\hline & \multicolumn{3}{|c|}{$\left(v_{3}\right) 1400-1600 \mathrm{~cm}^{-1}$} & \multirow{2}{*}{$\begin{array}{l}R^{2} \text { peak fit } \\
0.999\end{array}$} & \multicolumn{2}{|c|}{$\left(\nu_{2}\right) \sim 875 \mathrm{~cm}^{-1}$} & \multirow{2}{*}{$\begin{array}{l}R^{2} \text { peak fit } \\
0.993\end{array}$} & \multicolumn{3}{|c|}{$3200-3800 \mathrm{~cm}^{-1}$} & \multirow{2}{*}{$\begin{array}{l}\mathrm{R}^{2} \text { peak fit } \\
0.994\end{array}$} \\
\hline & 1416 & 1458 & - & & 875 & - & & 3230 & 3440 & 3568 & \\
\hline B10 & 1416 & 1472 & - & 0.998 & 875 & - & 0.994 & 3225 & 3451 & 3576 & 0.996 \\
\hline B30 & 1411 & 1453 & 1508 & 0.999 & 875 & - & 0.992 & 3270 & 3466 & 3584 & 0.996 \\
\hline B60 & 1410 & 1452 & 1509 & 0.998 & 875 & - & 0.992 & 3233 & 3456 & 3579 & 0.997 \\
\hline B120 & 1409 & 1452 & 1515 & 0.996 & 862 & 874 & 0.996 & 3254 & 3467 & 3583 & 0.998 \\
\hline B240 & 1410 & 1453 & 1521 & 0.997 & 868 & 875 & 0.998 & 3260 & 3461 & 3577 & 0.999 \\
\hline
\end{tabular}

Table 3

Mass losses and temperature intervals of thermal decomposition.

\begin{tabular}{|c|c|c|c|c|c|c|c|c|c|c|c|c|c|}
\hline \multirow[b]{2}{*}{ No } & \multicolumn{2}{|l|}{ B0 } & \multicolumn{2}{|l|}{$\mathrm{B} 10$} & \multicolumn{2}{|l|}{ B30 } & \multicolumn{2}{|l|}{ B60 } & \multicolumn{2}{|l|}{ B120 } & \multicolumn{2}{|l|}{ B240 } & \multirow[b]{2}{*}{ Description } \\
\hline & $\begin{array}{l}\mathrm{T}_{\text {infl. }}{ }^{*} \\
\left({ }^{\circ} \mathrm{C}\right)\end{array}$ & $\begin{array}{l}\text { ML, } \\
(\%)\end{array}$ & $\begin{array}{l}\mathrm{T}_{\text {infl. }} \\
\left({ }^{\circ} \mathrm{C}\right)\end{array}$ & $\begin{array}{l}\text { ML, } \\
(\%)\end{array}$ & $\begin{array}{l}\mathrm{T}_{\text {infl. }} \\
\left({ }^{\circ} \mathrm{C}\right)\end{array}$ & $\begin{array}{l}\text { ML, } \\
(\%)\end{array}$ & $\begin{array}{l}\mathrm{T}_{\text {infl. }} \\
\left({ }^{\circ} \mathrm{C}\right)\end{array}$ & $\begin{array}{l}\text { ML, } \\
(\%)\end{array}$ & $\begin{array}{l}\mathrm{T}_{\text {infl. }} \\
\left({ }^{\circ} \mathrm{C}\right)\end{array}$ & $\begin{array}{l}\text { ML, } \\
(\%)\end{array}$ & $\mathrm{T}_{\text {infl. }}\left({ }^{\circ} \mathrm{C}\right)$ & ML, (\%) & \\
\hline \multirow[t]{4}{*}{1} & 34.4 & 0.20 & 89.5 & 0.53 & 55.0 & 1.40 & 103.3 & 1.45 & 59.8 & 0.68 & 56.3145 .6 & 0.30 & \multirow{4}{*}{$\begin{array}{l}\text { Dehydration of physical and crystal } \\
\text { water }\end{array}$} \\
\hline & 116.5 & 0.20 & & & 142.7 & 0.60 & 250.8 & 0.59 & 126.3 & 0.91 & 280.8 & 0.60 & \\
\hline & & & & & & & & & & & 312.2 & 1.02 & \\
\hline & & & & & & & & & & & & 0.78 & \\
\hline \multirow[t]{2}{*}{2} & 462.5 & 1.23 & 467.7 & 0.72 & 458.0 & 0.83 & 468.3 & 1.10 & 467.9 & 1.28 & 439.4 & 0.92 & Dehydroxylation of HPP (B10- \\
\hline & & & & & 509.4 & 0.60 & & & & & 482.7 & 0.75 & $\begin{array}{l}\text { B240) [17] and Decomposition of } \\
\text { organic matter (B0) }\end{array}$ \\
\hline 3 & - & - & 559.2 & 0.95 & 556.7 & 1.23 & 534.7 & 1.36 & 564.5 & 1.82 & 578.8 & 0.93 & $\begin{array}{l}\text { Decarbonation (A-type } \\
\text { substitution) }[18,19,20,21,18,24 \text {, } \\
25,26,42]\end{array}$ \\
\hline \multirow[t]{2}{*}{4} & 703.5 & 5.74 & 697.3 & 4.29 & 615.2 & 1.57 & 613.0 & 2.60 & 591.7 & 1.37 & 629.0 & 1.35 & Decarbonation (B-type substitution) \\
\hline & & & & & 671.2 & 2.18 & 661.3 & 1.13 & 706.3 & 1.27 & 678.8 & 1.07 & $\begin{array}{l}{[11,19,22,23,24,18,24,27,28,29,} \\
37]\end{array}$ \\
\hline 5 & 847.7 & 1.44 & 760.7 & 0.76 & 758.8 & 0.54 & 758.1 & 0.52 & 755.1 & 0.53 & 751.5 & 0.79 & $\begin{array}{l}\text { Decarbonation of } \mathrm{CO}_{3} \text { from free } \\
\mathrm{CaCO}_{3}\end{array}$ \\
\hline \multirow[t]{2}{*}{6} & - & - & 815.0 & 0.31 & 803.7 & 0.58 & 839.6 & 0.91 & 827.4 & 1.04 & 822.7 & 2.70 & $\begin{array}{l}\text { Decarbonation (A-B-type } \\
\text { substitution) }[24,30,43,44,45,46]\end{array}$ \\
\hline & 11.20 & & 8.61 & & 12.10 & & 10.78 & & 11.97 & & 11.22 & & Total ML, (\%) \\
\hline
\end{tabular}

$\mathrm{T}_{\text {infl. }}{ }^{*}$ - Temperature in inflection point. 

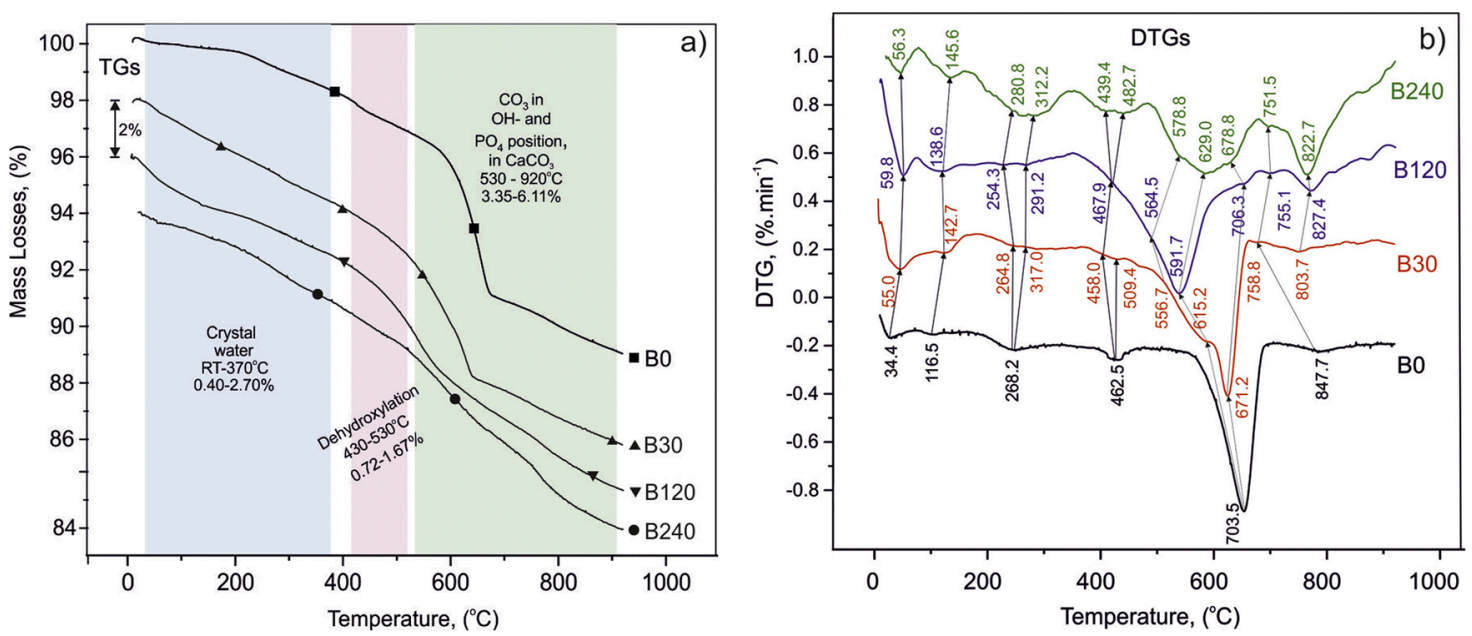

Fig. 4. Thermal analysis of B0, B30, B120, and B240: (a) TGs curves; (b) DTGs curves.

the other hand, the decrease of peak intensity close to $3550 \mathrm{~cm}^{-1}$ could be due to: (i) decrease of samples crystallinity [46] because of increased $\mathrm{CO}_{3}$ content or (ii) HEM-activation (Fig. 1) [53]. The results show decreasing intensities of both peaks due to the reduction of crystallinity of HEM-activation, proven by SSA measurements (Fig. 1).

The three peaks in the broad band at $3200-3800 \mathrm{~cm}^{-1}$ (Table 2) assumes the $\mathrm{OH}-\mathrm{F}$ substitution in the apatite structure $[54,55]$.

The position of the peak close to $3550 \mathrm{~cm}^{-1}$ defined the quantity of $\mathrm{OH}$ in the $\mathrm{F}$ position, whereas the peak shift to $3580 \mathrm{~cm}^{-1}$ displays an increase of $\mathrm{OH}$ (Table 2). The increase of $\mathrm{OH}$-content in the apatite structure appears as a result of the sample HEM-activation and supposes isomorphic transformation from raw FAp to HFAp.

The chemical mechanism of the isomorphic substitutions and the formation of the new phases could be presented by the following possible reactions:

$\mathrm{Ca}_{10}\left(\mathrm{PO}_{4}\right)_{6} \mathrm{~F}_{2} \rightarrow 3 \mathrm{Ca}_{3}\left(\mathrm{PO}_{4}\right)_{2}+\mathrm{CaF}_{2}$

$\mathrm{Ca}_{10}\left(\mathrm{PO}_{4}\right)_{6} \mathrm{~F}_{2}+\mathrm{H}_{2} \mathrm{O} \rightarrow \mathrm{Ca}_{10}\left(\mathrm{PO}_{4}\right)_{6}(\mathrm{OH}) \mathrm{F}+\mathrm{HF}$

$2 \mathrm{Ca}_{10}\left(\mathrm{PO}_{4}\right)_{6} \mathrm{~F}_{2}+2 \mathrm{H}_{2} \mathrm{O}+\mathrm{CaCO}_{3}+\mathrm{CO}_{2} \rightarrow 2 \mathrm{Ca}_{10}\left(\mathrm{PO}_{4}\right)_{5}\left(\mathrm{CO}_{3}\right)(\mathrm{OH}) \mathrm{F}_{2}+$ $\mathrm{CaH}_{2} \mathrm{P}_{2} \mathrm{O}_{7}$

$\mathrm{Ca}_{10}\left(\mathrm{PO}_{4}\right)_{6} \mathrm{~F}_{2}+\mathrm{H}_{2} \mathrm{O}+2 \mathrm{CaCO}_{3} \rightarrow \mathrm{Ca}_{9}\left(\mathrm{PO}_{4}\right)_{4}\left(\mathrm{CO}_{3}\right)_{2}(\mathrm{OH}) \mathrm{F}+\mathrm{Ca}_{3}\left(\mathrm{PO}_{4}\right)_{2}+$ $\mathrm{HF}$

$\mathrm{Ca}_{10}\left(\mathrm{PO}_{4}\right)_{6} \mathrm{~F}_{2}+\mathrm{H}_{2} \mathrm{O} \rightarrow \mathrm{CaH}_{2} \mathrm{P}_{2} \mathrm{O}_{7}+2 \mathrm{Ca}_{3}\left(\mathrm{PO}_{4}\right)_{2}+\mathrm{CaF}_{2}+2 \mathrm{CaO}$

and/or

$\mathrm{Ca}_{10}\left(\mathrm{PO}_{4}\right)_{6}(\mathrm{OH}) \mathrm{F}+\mathrm{H}_{2} \mathrm{O} \rightarrow \mathrm{CaH}_{2} \mathrm{P}_{2} \mathrm{O}_{7}+2 \mathrm{Ca}_{3}\left(\mathrm{PO}_{4}\right)_{2}+3 \mathrm{CaO}+\mathrm{HF}$

Taking into account the obtained formula of B0 - $\mathrm{Ca}_{10}\left(\mathrm{PO}_{4}\right)_{5}\left(\mathrm{CO}_{3}\right)$ $(\mathrm{OH}) \mathrm{F}_{2}$, the reactions (3) and (4) could be transformed in accordance with a possible increase of $\mathrm{CO}_{2}$ and $\mathrm{H}_{2} \mathrm{O}$ adsorbtion from the air as following:

$2 \mathrm{Ca}_{10}\left(\mathrm{PO}_{4}\right)_{5}\left(\mathrm{CO}_{3}\right)(\mathrm{OH}) \mathrm{F}_{2}+\mathrm{H}_{2} \mathrm{O}+2 \mathrm{CO}_{2} \rightarrow 2 \mathrm{Ca}_{9}\left(\mathrm{PO}_{4}\right)_{4}\left(\mathrm{CO}_{3}\right)_{2}(\mathrm{OH}) \mathrm{F}+\mathrm{CaH}_{2}$ $\mathrm{P}_{2} \mathrm{O}_{7}+\mathrm{CaF}_{2}+2 \mathrm{HF}$

$2 \mathrm{Ca}_{10}\left(\mathrm{PO}_{4}\right)_{5}\left(\mathrm{CO}_{3}\right)(\mathrm{OH}) \mathrm{F}_{2}+\mathrm{H}_{2} \mathrm{O} \rightarrow \mathrm{Ca}_{9}\left(\mathrm{PO}_{4}\right)_{4}\left(\mathrm{CO}_{3}\right)_{2}(\mathrm{OH}) \mathrm{F}+3 \mathrm{Ca}_{3}\left(\mathrm{PO}_{4}\right)_{2}+$ $2 \mathrm{CaO}+3 \mathrm{HF}$

$\mathrm{Ca}_{10}\left(\mathrm{PO}_{4}\right)_{5}\left(\mathrm{CO}_{3}\right)(\mathrm{OH}) \mathrm{F}_{2}+\mathrm{H}_{2} \mathrm{O} \rightarrow \mathrm{Ca}_{10}\left(\mathrm{PO}_{4}\right)_{5}\left(\mathrm{CO}_{3}\right)(\mathrm{OH})_{2} \mathrm{~F}+2 \mathrm{HF}$

\subsection{Thermally activated samples}

After thermal activation of HEM activated samples, the redistribution of $\mathrm{CO}_{3}, \mathrm{PO}_{4}, \mathrm{P}_{2} \mathrm{O}_{7}$, and Si-ions occurs, proven by PRXD and FTIR identification of new mineral phases (Figs. 2,3, Tables 1,2) and thermal effects by Thermal analysis are registered (Fig. 4, Table 3).

The accomplished measurements show solid-phase formation of new phases due to: (i) dehydration of physical and crystal water and dehydroxylation of HPP; (ii) decarbonation of carbonate substituted apatite phases and calcite; and (iii) partial transformation of $\mathrm{SiO}_{2}$ into $\mathrm{SiO}_{4}$ and $\mathrm{Si}_{2} \mathrm{O}_{7}$.

The dehydration of physical and crystal water is established via FTIR by reduced and/or lack of OH-structural bands in FAp, CHFAp, and HFAp (Fig. 3). The dehydroxylation of HPP is presented by transformation into PP (Table 1) as thermal analysis has registered ML in the first temperature range (Fig. 4, Table 3).

The decarbonation of calcite is proved with FTIR spectra due to the lack of $\mathrm{CO}_{3}$-calcite bands (Fig. 2), whereas PXRD does not identify calcite peaks (Table 1). The decarbonation of carbonate substituted apatite phases is seen from Fig. 3 - the $\mathrm{CO}_{3}$-apatite bands do not exist $[33,38]$. The thermal analysis also proves decomposition of apatite and calcite minerals: $\mathrm{ML}$ at $527-607^{\circ} \mathrm{C}$ show decarbonation of $\mathrm{CO}_{3}$ from $\mathrm{OH}$-position (A-type isomorphism) $[18,24-26,42]$, ML at $670-840^{\circ} \mathrm{C}$ decarbonation of $\mathrm{CO}_{3}$ from $\mathrm{PO}_{4}$-position (B-type isomorphism and A-B-type isomorphism), and of $\mathrm{CO}_{3}$ from calcite [18,24,27-29,37] (Fig. 4, Table 3).

The results from PXRD show that after HEM activation, the degree of isomorphic defects in apatite increases. According to thermal analysis, HEM activation influence has been determined in apatite structure defects by measuring $\mathrm{ML}$ in the three temperature ranges: i) $530-580^{\circ} \mathrm{C}$ (A-type isomorphism) (Fig. 5a); ii) $670-710^{\circ} \mathrm{C}$ (B-type isomorphism) (Fig. 5b); and iii) $800-840^{\circ} \mathrm{C}$ (A-B-type isomorphism) (Fig. 5c).

Fig. 5 a shows the exponential dependence of HEM activation time by ML for decarbonation of $\mathrm{CO}_{3}$ from $\mathrm{OH}$-position (A-type isomorphism) with the best fit: $y=\exp \left(0.167-0.011 x-4.792 \times 10^{-5} x^{2}\right)\left(R^{2}=0.94\right)$. The ML increase has been detected with the prolonged HEM activation time up to $120 \mathrm{~min}$ and a sharp decrease with prolonged activation time (240 min) (Table 3). The measured increase of ML from $0.95 \%$ to $1.82 \%$ is due to the increase of $\mathrm{CO}_{3}$ in $\mathrm{OH}$-positions, i.e. structural defects rise. This process has taken place with the SSA growth with prolonged time of HEM activation (Fig. 1) leading to fresh reaction surface increase. The additional amount of $\mathrm{CO}_{3}$ could be caused by $\mathrm{CO}_{2}$-diffusion from the air and by intrinsic system redistribution of $\mathrm{CO}_{3}$. The sharp decrease of measured ML for B240 is due to a lowering degree of A-type substitution. Such prolonged time of HEM activation, leads to particle aggregation $[19,21]$. This process cannot be detected by the measured SSA values (there is no substantial difference in the values of B120 and B240 Fig. 1), as they depend on the crystallite-to-aggregates size ratio, which 

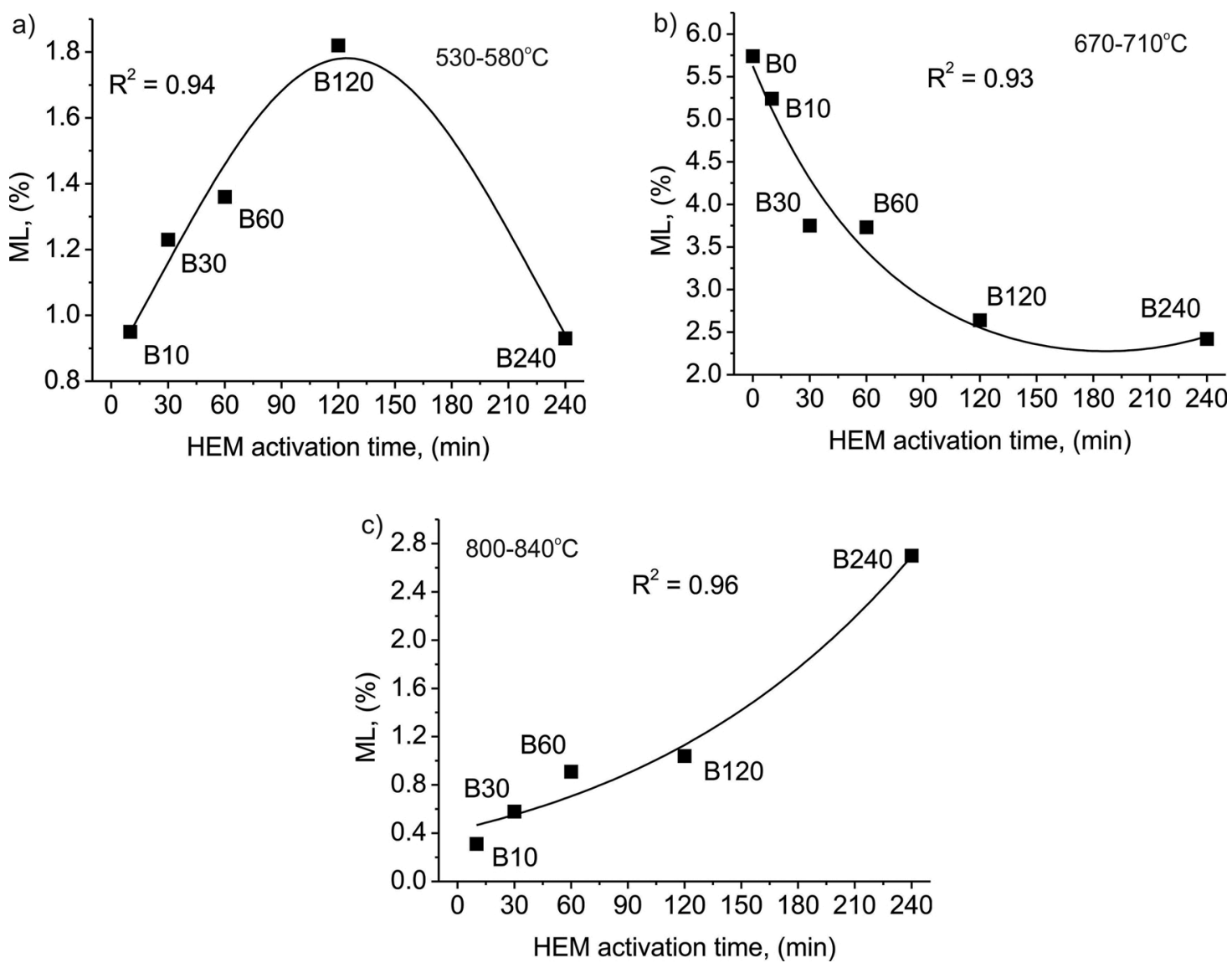

Fig. 5. HEM activation time dependence of the measured ML during apatite decarbonation and best fit to these data: (a) A-type substitution; (b) B-type substitution; (c) A-B-type substitution.

is also observed in previous studies in other HEM-activated materials eggshells [53] and bi-phase ceramic [56]. However, probably because of the particle aggregation sharp decrease of $\mathrm{CO}_{2}$ incorporation in the structure has been observed. It is likely that A-type defect formation is related to $\mathrm{CO}_{2}$ absorption from the air.

Fig. $5 b$ presents exponential decrease of ML with increase the HEM activation time for $\mathrm{CO}_{3}$ decarbonation from $\mathrm{PO}_{4}$-position (B-type isomorphism) with the best fit: $y=\exp (1.727-0.009 x+$ $\left.2.600 \times 10^{-5} x^{2}\right)\left(\mathrm{R}^{2}=0.93\right)$ in the temperature range of $670-710^{\circ} \mathrm{C}$. The reduction of mass losses from B0 (5.74 \%) to B240 (2.42\%) is by 58 $\%$, which shows a significant decrease in $\mathrm{CO}_{3}$ at B-type position. The latter is related to $\mathrm{CO}_{2}$ evolving of from the system and very likely to internal migration and position relocation of $\mathrm{CO}_{3}$ (from B- to other positions), both take place in the course of HEM activation.

Fig. 5c presents exponential growth of ML with increase the HEM activation time for $\mathrm{CO}_{3}$ decarbonation from $\mathrm{PO}_{4}$-position and vacancy (A-B-type isomorphism), with the best fit: $y=\exp (-0.747-0.008 x-$ $\left.0.355 x^{2}\right)\left(R^{2}=0.96\right)$. The ML rise from $0.31 \%$ (B0) to $2.70 \%$ (B240), i. e. by $88 \%$. This effect is a result of defect increase during HEM activation. As the rise of ML at A-B-type isomorphism is much higher (88\%) than the decrease of ML at B-type isomorphism (58\%), there could exist different mechanisms for position occupancy during HEM activation:

- Relocation of $\mathrm{CO}_{3}$-ions from B-type to A-B-type position;

- Redistribution of $\mathrm{CO}_{3}$-ions obtained after calcite decarbonation. Calcite is a mineral with low hardness and it is possible to partially decompose during HEM activation and $\mathrm{CO}_{3}$ to get distributed depending on the energy and thermodynamic state of the system. In addition, the measured ML from calcite decarbonation (Table 3, row 5) show a decrease from $1.44 \%$ (B0) to $0.52-0.54 \%$ (B30-B120).
- Incorporation of $\mathrm{CO}_{2}$ from the air.

The partial decomposition of FAp has been proved both by the decarbonation process and the shift of $\mathrm{PO}_{4}$ - bands in FTIR spectra [33, 38] which explains the detected $\beta$-TCP at B0 and, $\beta$-TCP at B240 by PRXD (Table 1).

$\mathrm{SiO}_{2}$ partially transforms into $\mathrm{SiO}_{4}$ and $\mathrm{Si}_{2} \mathrm{O}_{7}$. After $\mathrm{HEM}$ activation of samples, quartz accumulates energy in the structure [20] and remains stable because of its strong covalent bonds. The accumulated energy relaxed into heat leading to the destruction of the quartz (crushing) [20, 21]. During the subsequent high-temperature treatment accumulated heat energy released through solid phase reactions with the formation of spurrite, and tilleyite. These new phases are identified by PXRD and FTIR. Another new phase is registered - silicocarnotite (a member of silicocarnotite-ternesite solid solution [57]. Silicocarnotite crystalized under high-temperature conditions (artificial, calcium silico-phosphate phase in slag [58] and natural mineral, a product of pyrometamorphism [57]. In the studied case, silicocarnotite is a product of the interaction between FAp or/and $\beta$-TCP with larnite [58]. Larnite has not been identified. The spurrite and larnite PRDX positions are very close, which along with the low peaks intensity, do not allow larnite phase to be identified.

The detected new minerals are products of solid-state reaction as a result of decarbonation and $\mathrm{SiO}_{2}$-ion transformations. These effects are shown in Table 3. The last row displays increasing ML with decreasing temperature and rising HEM activation time.

The reaction mechanisms of samples thermal decomposition are as follows:

Sample B0:

The main reaction of thermal decomposition of apatite is presented 
by (1). Taking into account the identification of sample B0 as CHFAp, the reaction (1) is modified into decarbonation of CHFAp via $\mathrm{CO}_{3}$ from $\mathrm{PO}_{4}$-position:

$660-720^{\circ} \mathrm{C}$, Decarbonation of CHFAp $\left(\mathrm{CO}_{3}\right.$ from $\mathrm{PO}_{4}$-position $)$

$2 \mathrm{Ca}_{10}\left(\mathrm{PO}_{4}\right)_{5}\left(\mathrm{CO}_{3}\right)(\mathrm{OH}) \mathrm{F}_{2} \rightarrow 2 \mathrm{Ca}_{5}\left(\mathrm{PO}_{4}\right)_{3} \mathrm{~F}+2 \mathrm{Ca}_{3}\left(\mathrm{PO}_{4}\right)_{2}+\mathrm{CaF}_{2}+3 \mathrm{CaO}+$ $\mathrm{H}_{2} \mathrm{O}+2 \mathrm{CO}_{2}$

$800-910^{\circ} \mathrm{C}$, Decarbonation of calcite

$\mathrm{CaCO}_{3}=\mathrm{CaO}+\mathrm{CO}_{2}$

HEM activated samples (B10-B240)

Up to $370^{\circ} \mathrm{C}$, Dehydration of free physical and crystal water $430-530^{\circ} \mathrm{C}$, Dehydroxylation of HPP

$\mathrm{CaH}_{2} \mathrm{P}_{2} \mathrm{O}_{7}+2 \mathrm{CaCO}_{3} \rightarrow \mathrm{Ca}_{3}\left(\mathrm{PO}_{4}\right)_{2}+2 \mathrm{CO}_{2}+\mathrm{H}_{2} \mathrm{O}$

$\mathrm{CaH}_{2} \mathrm{P}_{2} \mathrm{O}_{7}+\mathrm{CaCO}_{3} \rightarrow \mathrm{Ca}_{2} \mathrm{P}_{2} \mathrm{O}_{7}+\mathrm{H}_{2} \mathrm{O}+\mathrm{CO}_{2}$

$530-920^{\circ} \mathrm{C}$, Decarbonation of $\mathrm{CO}_{3}$ from different types of isomorphic substitutions and $\mathrm{CO}_{3}$ from calcite:

$2 \mathrm{Ca}_{10}\left(\mathrm{PO}_{4}\right)_{5}\left(\mathrm{CO}_{3}\right)(\mathrm{OH}) \mathrm{F}_{2} \rightarrow 2 \mathrm{Ca}_{5}\left(\mathrm{PO}_{4}\right)_{3} \mathrm{~F}+2 \mathrm{Ca}_{3}\left(\mathrm{PO}_{4}\right)_{2}+\mathrm{CaF}_{2}+3 \mathrm{CaO}+$ $\mathrm{H}_{2} \mathrm{O}+2 \mathrm{CO}_{2}$

$\mathrm{CaCO}_{3} \rightarrow \mathrm{CaO}+\mathrm{CO}_{2}$

Solid-phase crystallization of spurrite and tilleyite from calcite and quartz:

$\mathrm{CaCO}_{3}+2 \mathrm{SiO}_{2} \rightarrow \mathrm{Ca}_{5}\left(\mathrm{SiO}_{4}\right)_{2}\left(\mathrm{CO}_{3}\right)+4 \mathrm{CO}_{2}$

$\mathrm{CaCO}_{3}+2 \mathrm{SiO}_{2} \rightarrow \mathrm{Ca}_{5} \mathrm{Si}_{2} \mathrm{O}_{7}\left(\mathrm{CO}_{3}\right)_{2}+3 \mathrm{CO}_{2}$

Solid-phase crystallization of spurrite and tilleyite from apatite, quartz and $\mathrm{CaO}$ :

$\mathrm{Ca}_{9}\left(\mathrm{PO}_{4}\right)_{4}\left(\mathrm{CO}_{3}\right)_{2}(\mathrm{OH}) \mathrm{F}+2 \mathrm{SiO}_{2}+2 \mathrm{CaO} \rightarrow \mathrm{Ca}_{5}\left(\mathrm{SiO}_{4}\right)_{2}\left(\mathrm{CO}_{3}\right)+2 \mathrm{Ca}_{3}\left(\mathrm{PO}_{4}\right)_{2}$
$+\mathrm{CO}_{2}+\mathrm{HF}$

$\mathrm{Ca}_{9}\left(\mathrm{PO}_{4}\right)_{4}\left(\mathrm{CO}_{3}\right)_{2}(\mathrm{OH}) \mathrm{F}+2 \mathrm{SiO}_{2}+2 \mathrm{CaO} \rightarrow \mathrm{Ca}_{5} \mathrm{Si}_{2} \mathrm{O}_{7}\left(\mathrm{CO}_{3}\right)_{2}+2 \mathrm{Ca}_{3}\left(\mathrm{PO}_{4}\right)_{2}+$ $\mathrm{HF}$

$\mathrm{Ca}_{9}\left(\mathrm{PO}_{4}\right)_{4}\left(\mathrm{CO}_{3}\right)_{2}(\mathrm{OH}) \mathrm{F}+2 \mathrm{SiO}_{2}+2 \mathrm{CaO} \rightarrow \mathrm{Ca}_{5}\left(\mathrm{SiO}_{4}\right)_{2}\left(\mathrm{CO}_{3}\right)+2 \mathrm{Ca}_{2} \mathrm{P}_{2} \mathrm{O}_{7}+$ $\mathrm{CO}_{2}+\mathrm{HF}$

$\mathrm{Ca}_{9}\left(\mathrm{PO}_{4}\right)_{4}\left(\mathrm{CO}_{3}\right)_{2}(\mathrm{OH}) \mathrm{F}+2 \mathrm{SiO}_{2}+2 \mathrm{CaO} \rightarrow \mathrm{Ca}_{5} \mathrm{Si}_{2} \mathrm{O}_{7}\left(\mathrm{CO}_{3}\right)_{2}+2 \mathrm{Ca}_{2} \mathrm{P}_{2} \mathrm{O}_{7}+$ $\mathrm{HF}$

$2 \mathrm{CaO}+\mathrm{SiO}_{2} \rightarrow \mathrm{Ca}_{2} \mathrm{SiO}_{4}$

Solid-phase synthesis of silicocarnotite:

$\mathrm{Ca}_{3}\left(\mathrm{PO}_{4}\right)_{2}+2 \mathrm{Ca}_{2} \mathrm{SiO}_{2} \rightarrow \mathrm{Ca}_{5}\left(\mathrm{PO}_{4}\right)_{2}\left(\mathrm{SiO}_{4}\right)$

\section{Conclusions}

After HEM- and thermal treatment, the redistribution of $\mathrm{CaO}, \mathrm{SiO}_{2}$, and $\mathrm{P}_{2} \mathrm{O}_{5}$ occurs as follows:

- Strength change of chemical bonds: $\mathrm{SiO}_{2}$ partially passes into $\mathrm{SiO}_{4}$ with the formation of new phases during thermal activation. The increased reactivity of $\mathrm{SiO}_{2}$ is a result of HEM treatment of the samples and after their thermal treatment, the solid-phase reactions of Ca-Si-carbonates crystallization occur;

- deformation of structural polyhedrons and formation of new isomorphic apatite phases after HEM activation: (i) $\mathrm{CO}_{3}$ both partially substitutes $\mathrm{P}_{2} \mathrm{O}_{5}$ and $\mathrm{OH}$ in two different positions and occupies the vacancy in apatite structure, as the degree of defects depends on HEM-activation time by functional dependencies; (ii) $\mathrm{OH}$ partially substitutes $\mathrm{F}$ in the apatite structure;
- the prolonged time of HEM activation leads to decreasing raw mineral stability leads to the formation of new phases: (i) $\mathrm{P}_{2} \mathrm{O}_{5}$ partially passes into $\mathrm{P}_{2} \mathrm{O}_{7}$ with the formation of new phases during both types of treatment; (ii) $\mathrm{CaO}$ after thermal treatment is transformed from Ca-carbonate into Ca-silicate, Ca-phosphate, and Ca-silicatecarbonate phases.

The obtained results can be used as a reference in the study of ceramic and cement materials (ancient and modern), soil conditioners, etc.

\section{Projects contributions}

The KP-06-PN-40/6 grant has sponsored the following activities: sample collection, sample preparation, and chemical analysis; the KP06-N39/9 grant - experiments and measurements of HEM activation, and results interpretation. The contribution of both projects is 50:50.

\section{Funding}

This work has been supported by the National Science Fund, Republic of Bulgaria [grant number KP-06-N39/9 (B.K., V.S., Zh.U) and grant number KP-06-PN-40/6 (Zh.U., B.K)].

\section{Declaration of Competing Interest}

The authors declare that they have no known competing financial interests or personal relationships that could have appeared to influence the work reported in this paper

\section{Acknowledgments}

The authors acknowledge the technical support from the Department of Natural Sciences, Laboratory of Geology - BF at NBU (B.K.) and of Institute of Mineralogy and Crystallography "Acad. Iv. Kostov", Bulgarian Academy of Sciences (V.P. of K2-2020). Special thanks to Mrs. Ina Maneva for the technical assistance.

\section{References}

[1] Z. Gou, J. Chang, W. Zhai, Preparation and characterization of novel bioactive dicalcium silicate ceramics, J. Eur. Ceram. Soc. 25 (2005) 1507-1514, https://doi. org/10.1016/j.jeurceramsoc.2004.05.029.

[2] L. Radev, V. Hristov, I. Michailova, M.H.V. Fernandes, I.M.M. Salvado, Collagen/ silicocarnotite composites, cross-linked with chondroitin sulphate: in vitro bioactivity, Process. Appl. Ceram. 5 (3) (2011) 161-170, https://doi.org/10.2298/ PAC1103161R.

[3] S.V. Maruti, R. Krishna, M. Mounesh, Properties of geopolymer cement mortar and blocks with calcium carbonate, Mater. Today Proc. 24 (2) (2020) 1518-1524, https://doi.org/10.1016/j.matpr.2020.04.471.

[4] R.A. Steinke, M.R. Silsbee, D.K. Agrawal, R. Roy, D.M. Roy, Development of chemically bonded ceramics in the $\mathrm{CaO}-\mathrm{SiO}_{2}-\mathrm{P}_{2} \mathrm{O}_{5}-\mathrm{H}_{2} \mathrm{O}$ system, Cem. Concr. Res. 21 (1) (1991) 66-72, https://doi.org/10.1016/0008-8846(91)90032-d.

[5] M. Catauro, A. Dell'Era, S. Vecchio Ciprioti, Synthesis, structural, spectroscopic and thermoanalytical study of sol-gel derived $\mathrm{SiO}_{2}-\mathrm{CaO}-\mathrm{P}_{2} \mathrm{O}_{5}$ gel and ceramic materials, Thermochim. Acta 625 (2016) 20-27, https://doi.org/10.1016/j. tca. 2015.12.004.

[6] J. Hu, D.K. Agrawal, R. Roy, Investigation of hydration phases in the system CaO-SiO $2-\mathrm{P}_{2} \mathrm{O}_{5}-\mathrm{H}_{2} \mathrm{O}$, J. Mater. Res. 3 (1988) 772-780, https://doi.org/10.1557/ JMR.1988.0772.

[7] I. Odler, Special Inorganic Cements (Modern Concrete Technology), Taylor \& Francis Ltd, United Kingdom, 2000.

[8] L. Maritan, I. Angelini, G. Artioli, C. Mazzoli, M. Saracino, Secondary phosphates in the ceramic materials from Frattesina (Rovigo, North-Eastern Italy), J. Cult. Herit. 10 (1) (2009) 144-151, https://doi.org/10.1016/j.culher.2008.01.008.

[9] L. Maritan, C. Mazzoli, Phosphates in archaeological finds: implications forenvironmental conditions of burial, Archaeometry 46 (4) (2004) 673-683, https://doi.org/10.1111/j.1475-4754.2004.00182.x.

[10] L. Maritan, Ceramic Materials, Archaeological Soil and Sediment Micromorphology, Wiley, Hoboken, NJ, 2017.

[11] S.F.S.R. Rodrigues, M. Lima da Costa, Phosphorus in archeological ceramics as evidence of the use of pots for cooking food, Appl. Clay Sci. 123 (2016) 224-231, https://doi.org/10.1016/j.clay.2015.10.038. 
[12] C.L. Giannossa, I.M. Muntoni, R. Laviano, A. Mangone, Building a step by step result in archaeometry. Raw materials, provenance and production technology of Apulian Red Figure pottery, J. Cult. Herit. 43 (2020) 242-248, https://doi.org/ 10.1016/j.culher.2019.11.002.

[13] P.J. Cook, J.H. Shergold (Eds.), Phosphate Deposits of the World: Volume 1: Proterozoic and Cambrian Phosphorites, Cambridge University Press, Cambridge, 2005.

[14] W.L. Pohl, Economic Geology: Principles and Practice. Metals, Minerals, Coal and Hydrocarbons - Introduction to Formation and Sustainable Exploitation of Mineral Deposits, Wiley-Blackwell, Oxford, 2011.

[15] V. Kovatchev, S. Strashimirov, P. Petrov, Non-metallic Ores, University of Minning and Geology, Sofia, 1991.

[16] S.K. Kawatra, J.T. Carlson, Benefication of phosphate. Society for Mining, Metallurgy \& Exploration, Englewood, Colorado, USA, 2014.

[17] J.C. Elliott, Structure and Chemistry of the Apatite and Other Calcium Orthophosphate, Studies in Inorganic Chemistry, Elsevier, Amsterdam, 1994. Hardcover ISBN: 9780444815828 ; eBook ISBN: 9781483290317.

[18] M.V. Chaikina, Mechanochemistry of Natural and Synthetic Apatites, Publishing house of SB RAS, Branch "GEO", Novosibirsk, 2002. ISBN 5-7692-0528-8.

[19] G. Hainike, Tribochemistry, Akademie-Verlag, Berlin, Münich, 1984.

[20] V.V. Boldyrev, K. Tkáčová, Mechanochemistry of Solids: Past, Present, and Prospects, J. Mater. Synth. Process. 8 (2000) 121-132, https://doi.org/10.1023/A: 1011347706721.

[21] P. Balaz, Mechanochemistry in Nanoscience and Minerals Engineering, Springer, Berlin Heidelberg, 2008. Print ISBN 978-3-540-74854-0. Online ISBN 978-3-540$74855-74857$.

[22] K. Tõnsuaadu, K. Rimm, M. Veiderma, Composition and properties of thermophosphates from apatite and aluminosilicates, Phosphorus Sulfur 84 (1993), https://doi.org/10.1080/10426509308034317, 1-4-73.

[23] L. Daasch, D. Smith, Infrared spectra of phosphorus compounds, Anal. Chem. 23 (1951) 6-853, https://doi.org/10.1021/ac60054a008.

[24] V. Petkova, V. Koleva, B. Kostova, S. Sarov, Structural and thermal transformations on high energy milling of natural apatite, J. Therm. Anal. Calorim. 121 (2015) 1-217, https://doi.org/10.1007/s10973-014-4205-5.

[25] S. Jebri, H. Boughzala, A. Bechrifa, M. Jemal, Structural analysis and thermochemistry of "A" type phosphostrontium carbonate hydroxyapatites, J. Therm. Anal. Calorim. 107 (2012) 3-963, https://doi.org/10.1007/s10973-011 1598-2.

[26] M.E. Fleet, X. Liu, Local structure of channel ions in carbonate apatite, Biomaterials 26 (2005) 36-7548, https://doi.org/10.1016/j.biomaterials.2005.05.025.

[27] V. Petkova, V. Yaneva, Thermal behavior and phase transformations of nanosized apatite (Syria), J. Therm. Anal. Calorim. 99 (2010) 1-179, https://doi.org/ 10.1007/s10973-009-0149-6.

[28] J.P. Lafon, E. Champion, D. Bernache-Assollant, R. Gibert, A.M. Danna, Thermal decomposition of carbonated calcium phosphate apatites, J. Therm. Anal. Calorim. (2003) 73-1127, https://doi.org/10.1023/A:1025036214044.

[29] F. Bel, H. Yahia, M. Jemal, Synthesis, structural analysis and thermochemistry of Btype carbonate apatites, Thermochim. Acta 505 (2010), https://doi.org/10.1016/j. tca.2010.03.017, 1-2- 22.

[30] K. Tonsuaadu, K.A. Gross, L. Plūduma, M. Veiderma, A review on the thermal stability of calcium apatites, J. Therm. Anal. Calorim. 110 (2012) 2-647, https:// doi.org/10.1007/s10973-011-1877-y.

[31] S. Pironkov, S. Marinova, Phosphorites. Non-metallic Ores. Technological and Economical Review, Tehnika, Sofia, 1991.

[32] Powder Diffraction File (PDF), ICDD, Newtown Square, PA.

[33] N.V. Chukanov, Infrared Spectra of Mineral Species: Extended Library, Volume 1, Springer Science+Business Media, Dordrecht, 2014, https://doi.org/10.1007/978 94-007-7128-4.

[34] M. Catauro, S.V. Ciprioti, E. Tranquillo, R. Risoluti, Sol-Gel Synthesis, Spectroscopic and thermal behavior study of $\mathrm{SiO}_{2} / \mathrm{PEG}$ composites containing different amount of chlorogenic acid, Polymers 10 (2018) 682, https://doi.org/ 10.3390/polym10060682.

[35] M. Catauro, F. Barrino, G. Dal Poggetto, G. Crescente, Pacifico. New $\mathrm{SiO}_{2}$ /caffeic acid hybrid materials: synthesis, spectroscopic characterization, and bioactivity, Materials 13 (2020) 394, https://doi.org/10.3390/ma13020394.

[36] M. Catauro, S. Piccolella, C. Leonelli, FT-IR characterization of antimicrobial hybrid materials through sol-gel synthesis, Appl. Sci. 10 (2020) 1180, https://doi. org/10.3390/app10031180.
[37] J.C. Elliott, The interpretation of the infra-red absorption spectra of some carbonate-containing apatites, in: M.V. Stack, R.W. Fearnhead (Eds.), Tooth Enamel: Its Composition, Properties, and Fundamental Structure, John Wright and Sons, Bristol, 1965, pp. 20-22, and p. 50-57.

[38] Th Theophile (Ed.), Infrared Spectroscopy, Materials Science, Engineering and Technology Croatia: Intech, 2012.

[39] T.V. Safronova, E.A. Mukhin, V.I. Putlyaev, A.V. Knotko, P.V. Evdokimov, Yu Filippov Ya, Amorphous calcium phosphate powder synthesized from calcium acetate and polyphosphoric acid for bioceramics application, Ceram. Int. 43 (2017) 1B-1310, https://doi.org/10.1016/j.ceramint.2016.10.085.

[40] J.R. Lehr, Crystallographic Properties of Fertilizer Compounds, Muscle Shoals, National Fertilizer Development Center, Alabama, 1967.

[41] R. Khaoulaf, A. Ennaciri, M. Ezzaafrani, F. Capitelli, Structure and vibrational spectra of a new acidic diphosphate $\mathrm{K}_{2} \mathrm{Cu}\left(\mathrm{H}_{2} \mathrm{P}_{2} \mathrm{O}_{7}\right)_{2} \cdot 2 \mathrm{H}_{2} \mathrm{O}$, Phosphorus Sulfur 188 (2013) 8-1038, https://doi.org/10.1080/10426507.2012.736096.

[42] D.U. Schramm, J. Terra, A.M. Rossi, D.E. Ellis, Configuration of $\mathrm{CO}_{2}$ radicals in girradiated A-type carbonated apatites: theory and experimental EPR and ENDOR studies, Phys. Rev. B (2000), https://doi.org/10.1103/PhysRevB.63.024107, 63-1.

[43] I.R. Gibson, W. Bonfield, Novel synthesis and characterization of an AB-type carbonate-substituted hydroxyapatite, J. Biomed. Mater. Res. 59 (2020) 4-97, https://doi.org/10.1002/jbm.10044.

[44] L. Muller, E. Conforto, D. Caillard, F.A. Muller, Biomimetic apatite coatings - carbonate substitution and preferred growth orientation, Biomol. Eng. (2007) 24-462, https://doi.org/10.1016/j.bioeng.2007.07.011.

[45] J.P. Lafon, E. Championa, D. Bernache-Assollant, Processing of AB-type carbonated hydroxyapatite $\mathrm{Ca}_{10-\mathrm{x}}\left(\mathrm{PO}_{4}\right)_{6-\mathrm{x}}\left(\mathrm{CO}_{3}\right)_{\mathrm{x}}(\mathrm{OH})_{2-\mathrm{x}-2 \mathrm{y}}\left(\mathrm{CO}_{3}\right)_{\mathrm{y}}$ ceramics with controlled composition, J. Eur. Ceram. Soc. 28 (2008) 1-139, https://doi.org/10.1016/j. jeurceramsoc.2007.06.009.

[46] M.E. Fleet, X. Liu, Coupled substitution of type A and B carbonate in sodiumbearing apatite, Biomaterials 28 (2007) 6-916, https://doi.org/10.1016/j. biomaterials.2006.11.003.

[47] S. Seesanong, C. Laosinwattana, B. Boonchom, A simple rapid route to synthesize monocalcium phosphate monohydrate using calcium carbonate with different phases derived from green mussel shells, J Mater Environ Sci 10 (2019) 2-113.

[48] A. Durif, Crystal Chemistry of Condensed Phosphates, Springer Science+Buisness Media, New York, 1995.

[49] P. Gras, S. Teychené, Rey Ch, C. Charvillat, B. Biscans, S. Sarda, et al., Crystallisation of a highly metastable hydrated calcium pyrophosphate phase, Cryst Eng Comm 15 (2013) 12-2294, https://doi.org/10.1039/C2CE26499D.

[50] N. Leroy, E. Bres, Structure and substitutions in fluorapatite, Eur. Cell. Mater. 2 (2001) 36-48, https://doi.org/10.22203/eCM.v002a05.

[51] M.E. Fleet, L. Xiaoyang, X. Liu, Orientation of channel carbonate ions in apatite: effect of pressure and composition, Am. Mineral. 96 (2011) 7-1148, https://doi. org/10.2138/am.2011.3683.

[52] V. Koleva, V. Petkova, IR spectroscopic study of high energy activated Tunisian phosphorite, Vib. Spectrosc. (2012) 58-125., https://doi.org/10.1016/j. vibspec.2011.09.010.

[53] B.V. Kostova, V. Petkova, M. Shopska, G. Kadinov, M. Balaz, P. Balaz, M. Kadiyski, Influence of high energy milling activation on nano-to-micro-sized $\mathrm{CaCO}_{3}$ crystallite formation, Fresenius Environ Bull 26 (2017) 1-426.

[54] L. Rintou, E. Wentrup-Byrne, Sh Suzuki, L. Grøndahl, FT-IR spectroscopy of fluorosubstituted hydroxyapatite: strengths and limitations, J. Mater. Sci. Mater. Med. (2007) 18-1701, https://doi.org/10.1007/s10856-007-3052-3.

[55] F. Freund, Ordering of $\mathrm{F}$ - along the $\mathrm{OH}-$-chains in apatite, Inorg Nucl Chem Lett (1977) 13-57.

[56] V.V. Kostov-Kytin, E. Dyulgerova, R. Ilieva, V. Petkova, Powder X-ray difraction studies of hydroxyapatite and $\beta$-TCP mixtures processed by high energy dry milling, Ceram. Int. 44 (2018) 8664-8671, https://doi.org/10.1016/j. ceramint.2018.02.094.

[57] E.V. Galuskin, I.O. Galuskina, F. Gfeller, B. Krüger, J. Kusz, Y. Vapnik, et al., Silicocarnotite, $\mathrm{Ca}_{5}\left[\left(\mathrm{SiO}_{4}\right)\left(\mathrm{PO}_{4}\right)\right]\left(\mathrm{PO}_{4}\right)$, a new 'old' mineral from the Negev Desert, Israel, and the ternesite-silicocarnotite solid solution: indicators of hightemperature alteration of pyrometamorphic rocks of the Hatrurim Complex, Southern Levant, Eur J Mineral 28 (2016) 1-105, https://doi.org/10.1127/ejm/ 2015/0027-2494.

[58] P. Ros-Tárraga, P. Mazón, L. Meseguer-Olmo, P.N. De Aza, Revising the subsystem nurse's A-Phase-Silicocarnotite within the system $\mathrm{Ca}_{3}\left(\mathrm{PO}_{4}\right)_{2}-\mathrm{Ca}_{2} \mathrm{SiO}_{4}$, Materials 9 (2016) 5-322, https://doi.org/10.3390/ma9050322. 